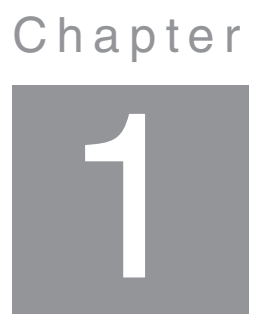

\title{
AN INTRODUCTION TO MICROFINANCE
}

"Where once the poor were commonly seen as passive victims, microfinance recognizes that poor people are remarkable reservoirs of energy and knowledge. And while the lack of financial services is a sign of poverty, today it is also understood as an untapped opportunity to create markets, bring people in from the margins and give them the tools with which to help themselves."

\section{- Kofi Annan, Nobel Peace Prize winner and former Secretary General of the U.N.}

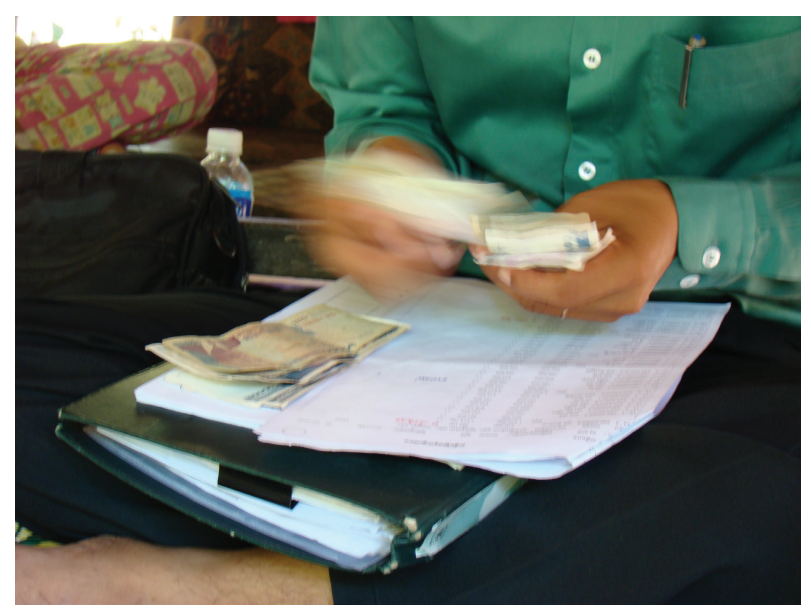

Figure 1.1. A field officer of Amret Microfinance disbursing funds in Siem Reap, Cambodia 
T he inequality of wealth distribution across the globe is no secret. One out of every three people in the world live on less than $\$ 3.10$ per day. Nearly one in 10 lives in extreme poverty, which according to the World Bank is an income of less than $\$ 1.90$ per day. ${ }^{1}$ The global distribution of poverty is uneven as well, with more than $75 \%$ of those living in extreme poverty living in South Asia or Sub-Saharan Africa. This sobering fact has driven various organizations such as the United Nations, World Bank, and many non-governmental organizations, or NGOs, to initiate programs targeted at reducing poverty. Microfinance is just one of many innovative tools in the global effort to shrink the wealth gap.

A common misconception is that microfinance is synonymous with microcredit: loans_-small ones. While it is true that microfinance has its origins in microcredit, as we will see throughout this book, it is now much more. Microfinance today involves a wide array of services for the poor and low-income people, from savings accounts to mobile money, insurance and many other services, both financial and non-financial such as healthcare and education.

\subsection{Microfinance Begins}

We begin our exploration where the microfinance industry started, with very small loans. In 1973 an antipoverty organization in Brazil called Accion noticed a high prevalence of small, informal enterprises that often needed funds to expand their business. Accion's staff members in the city of Recife, Brazil wondered: If these small business owners could borrow funds at commercial interest rates, could they start to lift themselves out of poverty? It was in this context that the first microfinance loan was granted. ${ }^{2}$

Within a few years, other institutions and individuals across the globe were also beginning to experiment with microcredit and with other microfinance services. The Bangladesh Rural Advancement Committee (BRAC), a nonprofit organization in Bangladesh, was also an early microlender. In 1976, similarly in Bangladesh, in the village of Jobra, economist Muhammad Yunus observed that if the poor were given access to credit they could pull themselves out of poverty. His first loan, a total of $\$ 27$ to a group of villagers, was an early experiment in group lending. By 1983 he had established the Grameen 
Bank, one of the most prominent microfinance institutions today with one of the strongest socially driven missions. Around the same time, the Indonesian state-owned bank, Bank Rakyat Indonesia (BRI), also began to experiment with not only microloans but also microsavings.

Accion, BRAC, BRI, and Grameen Bank soon discovered something remarkable: the poor could save money, and they could borrow money and reliably repay with interest. What set these pioneering organizations apart from earlier efforts at banking for the poor is that they all found ways to expand to serve very large numbers of the poor without subsidies. They treated financial services for the poor like a business that could sustain itself, and in some cases even turn a profit. All of these organizations continue to lend to the poor today. Their initial successes proved that the poor often have the skills and drive to enhance their incomes and the well-being of their families if they have access to finance or ways to save. The idea that the poor can lift themselves out of poverty is at the heart of microfinance.

The success of the early pioneers also demonstrated that microfinance can be a sustainable, business-minded intervention in efforts to reduce global poverty. The early experiments inspired the creation of new microfinance institutions (MFIs), organizations that offer financial services to the poor. Initially, many MFIs financed their operations through donors and grants, and many today still rely on charitable contributions. However, in the decades since the 1970s, hundreds of MFIs have matured to become fully commercial enterprises that by charging interest and service fees cover their costs and earn profits. MFIs that can fully cover their operational costs (and therefore do not need donations) are called self-sufficient or sustainable, suggesting that if run properly they can serve the poor in perpetuity.

Since Accion's experiment in Recife, microfinance has grown from the obscure efforts of a few philanthropic institutions into an industry that reaches more than 200 million clients through the branches of many thousands of institutions. ${ }^{3}$ Microfinance has matured from funding exclusively micro business loans to providing savings, insurance, mortgages, mobile banking, healthcare, and education. The public has become increasingly aware of the industry, in part due to the success of Yunus, who received the Nobel Peace Prize in 2006. More recently, in 2009 American President Barack Obama awarded him the Medal of Freedom, the highest American civilian honor. 
Despite microfinance's long history, impressive growth, and Nobel nod, many Westerners still do not know what microfinance is. However, visit a poor village or slum in Brazil, and seemingly everyone can tell you what microfinance is. Visit Peru, one of the most saturated and competitive microfinance markets, and discover the personal stories almost anyone can tell of how microfinance has touched their lives, or the lives of someone they know-both the good and the bad. But for those of us further removed from day-to-day microfinance, the questions remain: What is microfinance? What are its methods? Does it work? What are its prospects and challenges? This book tackles those questions and more.

\section{Section in Bulletpoint}

- One-third of the world's population lives on less than $\$ 3.10$ per day.

- Microfinance began in the 1970s in Brazil, Bangladesh, and Indonesia.

- Microfinance can be a sustainable poverty alleviation tool that covers its own costs while empowering the poor by giving them the financial tools to lift themselves out of poverty.

- More than 200 million clients now use microfinance services offered by many thousands of institutions worldwide.

\section{Discussion Questions}

1. According to World Bank statistics (easy to find online), is the fraction of people living on incomes below $\$ 3.10$ per day rising or falling globally? What regions have experienced the biggest changes?

2. Think of some other methods, beyond microfinance, to alleviate poverty. Which are self-sustainable, i.e. covering their own costs, and which are not? Discuss why an institution that aims to alleviate poverty may invest in non-sustainable methods.

3. Do you think microfinance alone is enough to alleviate poverty? Why or why not?

4. Try to list all of the financial services you currently use; things like savings accounts, credit cards, and ATM withdrawals. Many people in 
developed countries use more than 20 such services, so you probably use more than you initially realize. Now imagine living without these financial services. How important do you think financial services are to your way of life? If your income increases, does your need for financial services increase or decrease? In what way?

\subsection{Microfinance Defined}

Simply stated, microfinance refers to the offering of financial services to poor and low-income people. Traditionally, the poor have been considered "high risk" and have not been well served by institutions like banks, mutual funds, and credit card companies. A central goal of microfinance is poverty alleviation, by building, as Robert Christen of the Gates Foundation and his colleagues put it, "a world in which as many poor and near-poor households as possible have permanent access to an appropriate range of high quality financial services, including not just credit but also savings, insurance, and fund transfers." ${ }^{\prime}$

As we will see in Chapter 2, just like you, people living in poverty need access to financial services to help them provide for their families, save for big expenses like weddings, funerals or school fees, smooth out fluctuations in income streams, run their businesses, build assets, and manage risk. As we will explore in Chapter 3, the traditional banking and finance sector has until recently largely not served the poor, denying them access to savings accounts, insurance products, or credit to finance their small business enterprises. The poor are often turned away because they do not have a preexisting financial history, cannot afford traditionally high fees for banking services, have limited or no assets that might serve as collateral to secure loans, have no credit record or documentation of employment, and sometimes cannot read or write to fill out the paperwork for bank accounts or loans.

\section{Can the Poor Really Use Financial Services?}

Many poor people without access to financial services can immediately benefit from the availability of savings, insurance and credit. Even though the poor do not have much money, they still need and regularly use financial services. In fact, the poor across the globe have long developed informal 
financial services to meet this demand. Some practices date back to ancient civilizations, such as storing wealth in the form of cash crops or livestock, stashing currency or valuable objects within the home, and borrowing from close-knit communities and family. The first record of money lending dates back 3,000 years to the ancient Sumerian city of Uruk, south of modernday Baghdad, Iraq. Other historical financial services include insurance-like cooperative burial clubs in Ancient Greece and Ancient Rome that covered funeral costs for deceased members or others in their families. The first recorded loan agreement that included interest dates back to 172 B.C. in Egypt. In short, money-oriented services aimed at the poor are certainly not second-millennia fads; even William Shakespeare in the 16th century featured a persecuted moneylender, Shylock, in The Merchant of Venice.

Fortunately, informal financial services have come a long way since ancient times. As we will see in Chapter 4, the poor also participate in savings and credit cooperatives in which groups of community members create their own informal village banks. Often such informal cooperatives even write charters and hold their members accountable to the rules of the union. Members usually contribute a small amount of funds regularly as savings. Members can then borrow from the large cumulative fund, which they must pay back. Rotating savings clubs, found in nearly every culture worldwide, work similarly. Participants save a small amount periodically, often weekly. Members take turns taking the weekly pot of saved currency. Similarly, tens of thousands of collaborative, informal so-called "friendly societies" emerged in the United Kingdom in the 19th century to provide credit, savings and insurance services to millions of poor and working class people. In the developing world today, collectors still walk through villages taking and protecting people's savings for a small fee in exchange for this informal service.

Still, these informal savings and lending methods are risky because their informality means that they offer no legal protection to the participants. For example, what is to stop a credit cooperative member from not paying back a loan? Or participants with an early turn in the rotating savings clubs from taking the whole pot when it is their turn and then refusing to contribute their fair share to others later in the rotation? Cash crops used to store wealth can spoil, livestock can die, currency in the mattress can get stolen, and moneylenders can charge very high fees if borrowers have no other options in times of need. 
The poor need access to safe savings methods—ideally, methods that earn interest and have limited fees. People sometimes need loans, hopefully with interest rates that are reasonable, not so high that they force borrowers to be indebted to lenders forever. The poor also need access to more than just savings and credit. For example, the poor can have large families entirely dependent on income from one provider in a dangerous job or on crops that big storms can wipe out. As a result, they need life insurance or crop insurance. Another common financial service in demand is remittances, which are money transfers from family members or friends working in cities or abroad in more developed nations back to those living in rural areas. In short, the poor need access to a full range of financial products. Microfinance was born from this demand.

\section{Box 1.1. Faces \\ Felix Loyola's Story as Told to Jose Arias}

Felix Loyola was born a campesino-a fieldworker. Since he began working at the age of nine, Felix grew up believing he was stuck in a place he thought he would never leave. He harvested agave cacti for tequila, bananas, guavas, and, his favorite, mangoes. He earned less than $\$ 1$ a day and was living a life of hungry days and cold, sleepless nights. When he married his wife, Luciana, he realized his situation needed to change. He dreamed of having children who could read and write, would go to college, and live a better life than he had. Growing up among the freshest ingredients Mexico had to offer, he and his wife decided they wanted to open a restaurant. Unfortunately, Felix did not have any capital to begin with. In 1998 Compartamos Banco was developing a lending group in a town nearby called Miacatlan. Felix heard that a bank was giving out small loans to people who had no assets. He and his wife traveled to Miacatlan, and were selected as key members of this group. In October of 1998, Felix took out his first loan of $\$ 95$ with an annual interest rate of $25 \%$. He quickly allocated the newfound capital to buying a large griddle and chickens in order to make his "tacos famosos." Today, Felix owns a modest restaurant

(Continued) 


\section{Box 1.1. (Continued)}

outside of Miacatlan, and both his children are attending a local private school.

Felix Loyola's story is a true account of one man's experience with microfinance as he himself told it to Jose Arias in January of 2009. Jose was, at the time, a sophomore enrolled in an introductory microfinance course at Lehigh University as well as an active member of the university's microfinance club and co-contributor to this text. Being of Mexican descent with relatives still living in Mexico, Jose decided to call his grandfather and ask if he knew anything about microfinance or knew of anyone who borrowed from a microfinance institution. His grandfather responded enthusiastically, divulging his own knowledge of microfinance before mentioning Felix's name. He gave Jose Felix's number and Jose called Felix to interview him over the phone for his own personal story.

Source: Jose Arias, personal communication.

\section{Microcredit: The Roots of Microfinance}

Services offered by microfinance institutions (MFIs) now range from loans, savings, and insurance to money banking, healthcare, and well beyond. Yet microcredit, the offering of small, uncollateralized loans, is where microfinance has its roots and is the topic of Chapter 5. The prefix "micro" comes from the fact that the loans (or savings, for microsavings) tend to be very small. In developed countries like the U.S. and in Europe, a smallish loan for a business may mean $\$ 10,000$, but in the developing world, $\$ 100-100$ times less - may be enough to start an informal microenterprise or to escape from perpetual reliance on local moneylenders who charge high fees. A hundred dollars in savings can mean the difference in whether or not a family can send children to school, or maybe even whether the kids can eat for a month if mom or dad falls too sick to work.

Most microcredit agreements, like most loans outside of family or close friends, come with interest. At first, the notion of charging interest to a 
person who earns only a dollar a day may seem inhumane. As we explore in Chapters 8 and 9, many advocates for the poor argue that microcredit with high interest can do more harm than good, trapping clients in endless cycles of debt they cannot repay. On the other hand, proponents of the industry point out that by charging interest, MFIs can operate without huge subsidization or dependency on donor funds.

Self-sufficient MFIs charge fees and interest rates that allow them to cover their costs and stay in business. Unfortunately, administrative and processing costs are typically much higher than at traditional commercial banks. It is much more time consuming and expensive to lend 5,000 small $\$ 200$ transactions than to lend out just one commercial business loan worth the same $\$ 1$ million. That is because processing and administrative costs are not directly dependent on the size of the loan. It costs essentially the same to process a $\$ 100$ loan as a $\$ 1000$ one. Suppose a transaction costs the bank $\$ 25$ either way. The interest rate would need to be $25 \%$ just to break even on the $\$ 100$ loan but only $2.5 \%$ for the $\$ 1000$ loan. Furthermore, because the poor often live in hard-to-reach rural places and cannot readily trek into a city branch, MFI staff may need to travel to the borrowers, adding costs in terms of fuel and hourly wages.

According to the Consultative Group to Assist the Poor (CGAP), an independent policy and research center that focuses on the spread of financial services to the poor, globally the average annual interest rate charged by an MFI in 2011 was 27\%.5 Although an interest rate of $27 \%$ sounds high compared to loans like mortgages in developed countries, it is comparable to many credit card rates. Moreover, it is far below what informal moneylenders typically charge, annual percentage rates that often run in the hundreds, and in some places, thousands of percent. Of course, just because the poor have few alternatives, MFIs aiming to help them presumably should not try to extract the highest possible fees. Unfortunately, some MFIs do charge high rates $-70 \%$ or $90 \%$ annual interest are unusual but not unheard of - to cover inefficient operations or generate higher than normal profits for investors. Nevertheless, the majority of MFIs stay true to their social mission and strive to keep charges to their clients down by improving efficiency, achieving economies of scale and, increasingly, through innovation. Indeed, one recent analysis concluded that inflation-adjusted interest rates (including fees etc.) in 2009 were about 20\% in South Asia and 30-35\% throughout the rest of the world; and four-fifths of microcredit clients paid $35 \%$ a year or less. ${ }^{6}$ 
Beyond covering costs, charging fees and interest also allows MFIs to generate more funds with which to expand their outreach and services to even greater numbers of the poor. Today, hundreds of millions of clients willingly use MFIs and are willing to pay, suggesting they get value from the services. Given how broad and complex the microfinance industry has become, both sides of this debate are undoubtedly true. Some low-income clients thrive, while others struggle. Some MFIs' methods can do harm; other MFIs deeply improve lives. We explore these contradictions and the evidence on both sides throughout the book.

\section{Group Lending}

A key innovation in the success of microcredit is the practice of group lending (explored in detail in Chapter 5), forms of which are sometimes called solidarity groups or village banking. Not all microfinance loans are done in groups_-individual loans are increasingly common-but the practice still dominates the industry in various regions. The group lending innovation came in response to obstacles financial institutions face when serving the poor. Recall that commercial banks often do not lend to the poor because they lack sufficient financial history and collateral, and also because accounts are small and tend to have high transactions costs per account. Well, MFIs face these same obstacles. For example, how are MFIs to distinguish between people who are good and bad credit risks without some sort of previous records? Without collateral how can they protect themselves against late payments (called delinquency) or failure to repay the loan (called defaulting)?

Group lending is one approach to combating all three problems: insufficient client information, lack of collateral, and high operating costs per transaction. The MFI lends funds to a group of people, often about five or six, though the groups can grow quite large to even 20 or 30 individuals. The total amount loaned to the group is the account figure on the MFI's books, all disbursed and repaid at the same time. Thus, by pooling several clients into one loan agreement, MFIs keep their costs per client in check.

It also helps the MFIs feel more comfortable about potential risks, because the groups self-select. Community members know each 
other well and have information the MFI lacks about potential clients. Potential clients will only want to enter agreements with others they believe to be reliable, because if they misjudge their peers then the group as a whole is liable for any financial delinquency on the part of any of the group's participants. In other words, if Sonja fails to make her payments this month, the rest of the group must chip in to meet Sonja's payment obligation. In this way the group behaves as collateral. As for Sonja, she would eventually have to pay back her group or face the consequences, which range from a bruised reputation in her community (with consequences in the future should she need community support) to exclusion from lending groups in the future.

\section{Box 1.2. In Your Backyard Microfinance in Arkansas}

Microfinance's potential to help alleviate poverty might work in wealthy countries as well as poor countries. However, developed countries have different hurdles to overcome in regard to poverty. For example, critics point out that in many developing countries self-employment is commonplace and accounts for the majority of microfinance clients, while in the U.S. the self-employed make up less than $10 \%$ of the workforce. Furthermore, most new small businesses in the U.S. fail within a few years, bringing into question their ability to repay loans. So too, there is already a wide array of financial services available in the U.S. Can microfinance add anything?

It was not until the 1980s that the U.S. began to really look at microfinance as a means of poverty reduction. In 1985, then-Governor Bill Clinton approached Muhammad Yunus, founder of the Grameen Bank, and asked him to implement a microfinance program in Arkansas. However, before a program could be designed and launched, Yunus wanted to discover for himself what American poverty looked like and see if there was any truth in the critics' concerns.

In February 1986 Yunus met with some of the poorest residents in Arkansas and asked them what they would do with a bank loan. 


\section{Box 1.2. (Continued)}

Slowly, poor Arkansans began to describe to Yunus their business ideas, and their entrepreneurial spirit gave him hope that a microcredit program could be implemented in the U.S. In Pine Bluff, Arkansas, the Good Faith Fund was piloted. The program showed promise, and so the model was repeated across the country, in places like South Dakota, Oklahoma, and Chicago, reaching urban, suburban, and rural American communities alike.

However, microfinance has never quite caught on in the U.S. or other high-income economies as much as in developing countries, though it is certainly growing. Part of the reason microfinance is slow to catch on in rich countries stems from differences between the needs of the poor in developed and developing countries, such as the scale of funding needs. Accion, one of the largest MFIs currently operating in the U.S., says its average microloan granted in the U.S. is about $\$ 10,000$, with a range to $\$ 50,000$, or in some cases even $\$ 1$ million. Compare this to the average $\$ 500$ loan of Accion's affiliate Compartamos Banco in Mexico. Furthermore, while the poor in the U.S. are often refused loans for the same reasons as are the poor in developing countries-lack of financial history and insufficient collateral-group lending does not seem to work in the U.S. as it does in developing countries. A partial explanation may be that American culture is more individualistic, though an alternative theory lies in the fact that American microcredit borrowers graduate from MFIs to commercial banks faster and more frequently than their developing nation counterparts. This, coupled with competition from other financial service options-e.g. local credit unions, payday lenders, credit card companies, and government small business assistance programs - reduces the potential for economies of scale. As a result, funding needs and operational costs for microfinance institutions in the U.S. are higher per client than in most developing countries.

Still, both Grameen America and the Accion U.S. Network have active programs, each with tens of thousands of clients in the U.S.,

(Continued) 


\section{Box 1.2. (Continued)}

suggesting microfinance can work in the developed world. However, it must do so under excellent management; even then large-scale growth remains elusive.

Sources: Yunus (1999), and About the Accion U.S. Network, http://us.accion.org/usanetwork.

In practice, the repayment rates of microcredit borrowers, both in groups and as individuals, have been remarkably high, above $95 \%$ for well-managed MFIs and even near 99\% for some. Those sorts of results have helped the industry grow by creating faith within the industry that the social collateral of groups is an effective substitute for client information and collateral. In turn, lenders and investors have become more willing to provide loans to the poor. The poor have turned out to be a low-risk investment.

Furthermore, it may be that the flexibility and incentives for repeat loans may be more important than social pressure. In many MFIs, if a borrower or a group successfully repays, each subsequent loan can be larger than the last, called progressive lending - a system that creates incentives for repayment. Individual loans are steadily rising as a fraction of microcredit. More than a quarter of 1,080 leading MFIs in a 2009 survey were primarily individual lenders. ${ }^{7}$ Even the pioneer Grameen Bank has dropped group joint-liability lending altogether, although it retains group meetings. Nevertheless, group lending remains a principal method for thousands of MFIs worldwide, particularly those aiming at providing financial access to the poorest clients.

\section{Savings and Beyond}

We have already seen that the poor have various informal methods of saving on their own, such as storing cash or livestock, but these methods carry risks-and in the case of livestock, expenses too. As we discuss in more detail in Chapter 2, the poor must save, even more than most. Otherwise, their income could not cover traditional large costs, such as weddings and funerals, school fees for their children, or investment opportunities like acquiring a dairy cow to sell milk. Many poor also often suffer significant unpredictable day-to-day fluctuations in income and might go without any income for days or weeks. Savings tools that allow them to store money 


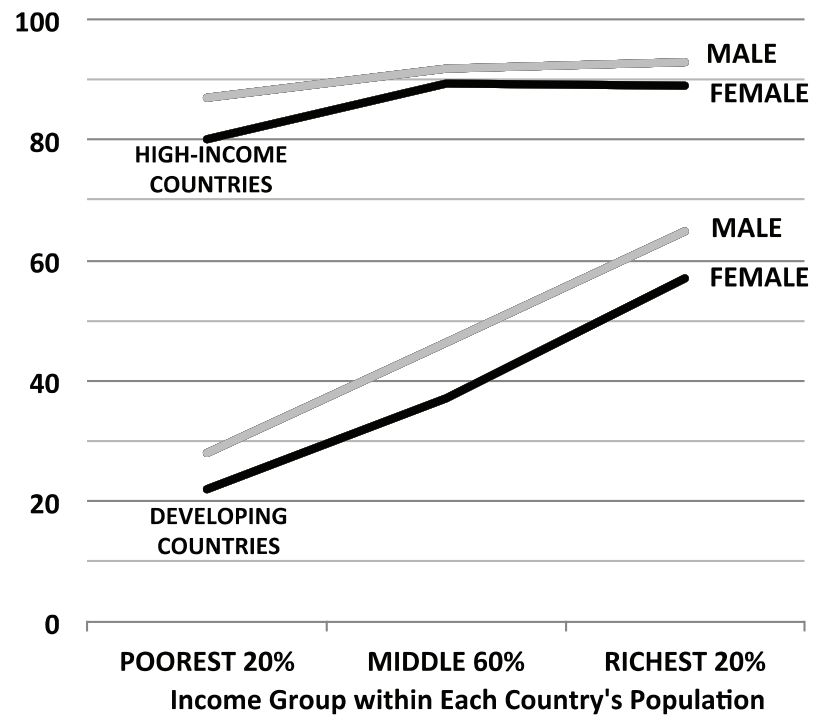

Figure 1.2. Adults worldwide with an account at a formal financial institution (\%) Source: Demirgüç-Kunt and Klapper (2012).

from good income days can help them smooth out their purchases of food and other basic consumption to get through the irregular ups and downs. Furthermore, just like you, the poor need savings in case of emergencies, such as illness or natural disasters.

By offering savings accounts, banks provide a safe, secure, and formal way to build funds. Yet the commercial banking sector is often hard to access physically and financially. Branches may not be located conveniently within a rural village and banks often have minimum deposit requirements. As a result, according to a worldwide survey by the World Bank and Gallup, more than three of every four of the poorest people in developing economies lack any sort of formal account, savings or otherwise, at any financial institution (see Figure 1.2). The poor lack access to savings accounts that allow for tiny, frequent deposits, are physically accessible, and easy to withdraw funds from when needed. Encouragingly, innovative MFIs like BRI have found ways to provide accessible savings accounts that are also financially viable from an institutional perspective. Note, however, that most governments try to protect people and their 
savings from dishonest operators. So, not just any institution can take deposits, only licensed and regulated formal banks can. For this reason, in recent years a substantial number of MFIs are changing from being NGOs (which lack legal status to take deposits) to being formally licensed banks, as we explore further in Chapter 8.

\section{Box 1.3. In the Field BRI Mobilizes Savings}

Bank Rakyat Indonesia is one of the pioneers of savings mobilization. It was one of the first MFIs to realize that the poor not only could save but also need to save. All of its clients have deposit accounts, while not all are borrowers.

\section{Table 1.1. Bank Rakyat Indonesia}

Began commercial 1984

microfinance

\begin{tabular}{ll}
\hline Location & Indonesia \\
\hline Clients (Dec. 2015) & 43 million microsaving customers; \\
& 7.9 million borrowers \\
\hline Women as \% of borrowers & $60 \%$ \\
\hline Self-sufficiency ratio* & $135 \%$ \\
\hline Legal status & Commercial bank, stock traded \\
\hline
\end{tabular}

Note: * Self-sufficiency ratio is a measure of whether an MFI is covering its expenses. If the ratio (financial revenue/financial expenses + operating expenses) is below $100 \%$, the MFI needs subsidies to operate.

BRI by 2015 had grown to 43 million microsavings client accounts and boasted a microsavings deposit portfolio of $\$ 14$ billion. Its own borrowers' savings have become the bank's primary source of funding, allowing it to become completely self-sufficient and independent of all governmental or private donor funds. BRI has taken microsavings to the next level by also providing more than 22,000 ATMs-including some mobile ones on boats to reach remote areas - and more than 10,000 accessible branches throughout the many islands that make up Indonesia. 


\section{Box 1.3. (Continued)}

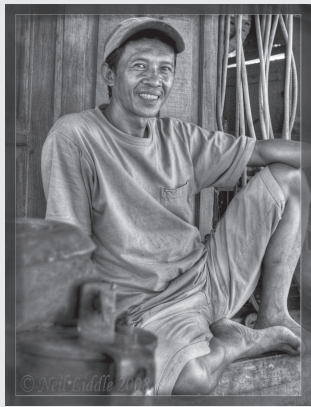

Figure 1.3. Owner of a tambal ban, tire repair business, in Gorontalo, Indonesia Note: Millions of Indonesians like him use local BRI branches for their savings. Source: (C) Neil Liddle, 2008†

The importance of this self-sufficiency became clear during the deep Asian financial crisis in the late 1990s. Bank customers throughout much of Asia lost faith in their banking systems, causing many banks to collapse. In Indonesia alone 82 other banks failed and 13 more were taken over by the government. Yet BRI survived. The microsavings business saved the bank because during the crisis BRI's millions of savers kept their trust and funds in BRI's local branches.

Source: Bank Rakyat Indonesia, Annual Report 2015.

${ }^{\dagger}$ Licensed under Creative Commons Attribution 2.0: https://creativecommons.org/licenses/by/2.0/legalcode.

Increasingly, MFIs are doing even more than providing financial services. Today, it is common to see institutions provide services such as free business training, empowerment workshops, and healthcare. This is because MFIs have found that poverty is more than just a financial problem. Poverty can also mean inadequate housing conditions, lack of healthcare, and lack of education. For these reasons, microfinance cannot exist in a vacuum. It is but one tool, a financial tool, in poverty reduction. There is still much work to be done by charitable and government organizations alike around the globe. 


\section{Section in Bulletpoint}

- Microfinance provides financial services of all sorts to the poor and low-income people around the globe.

- The poor are often excluded from the formal financial sector because traditional banks consider them too risky and costly.

- Thus, the poor often resort to informal methods of saving and borrowing that leave them legally unprotected in the event of fraud or disaster.

- Microcredit, one part of microfinance, involves small loans to the poor and low-income people.

- Microcredit began with loans to groups that share liability for repayment of all group members' loans, a key innovation that helped the industry grow.

- Beyond microcredit, microfinance now includes a full suite of services including savings, insurance, healthcare and education, among many others.

- Some microfinance institutions are limited in the services they can offer based on their legal status. For example, in many countries, only banks can take savings deposits.

- Microcredit interest rates tend to be higher than traditional commercial rates because of higher operating cost ratios.

\section{Discussion Questions}

1. Why are the poor often excluded from the formal financial sector? Can you think of any other reasons not discussed in the chapter?

2. What are some innovations of microfinance that address the challenges of serving the poor?

3. Why do microfinance institutions charge interest on microloans? Why are the interest rates so high?

4. How does group lending help MFIs manage the loans they give out? Briefly discuss advantages and disadvantages of this method. 


\subsection{Microfinance as an Industry}

\section{How Big Is Microfinance and Who Uses It?}

The microfinance industry has certainly come a long way since the 1970 s. The dawn of microfinance was the work of only a handful of institutions, namely Accion, Grameen Bank, BRI, FINCA, ASA, and BRAC. Today, there are probably more than 10,000. By 2012 there were more than 3,700 MFIs reporting data to the Microcredit Summit Campaign, which tracks industry data and promotes industry goals and policy. However, thousands of additional smaller institutions do not report data, so exact numbers are unavailable. Part of the complexity stems from the fact that MFIs can take on many forms: some are commercial banks, while others are nonbank financial institutions; some are government-owned, and others are NGOs. Many MFIs are part of organizations like NGOs or churches that primarily deal in other charitable activities or implement microfinance in a manner different from the standard, so they are difficult to define or count. Still, even without exact numbers, the growth of the industry is impressive. It went from a handful of organizations to many thousands. The early pioneers showed the world that microfinance could work and sustainably achieve large scale; and the industry boomed.

Data on the number of people using microfinance also provide a picture of rapid growth. According to Microcredit Summit Campaign estimates (Figure 1.4), at the end of 1997 there were 13 million clients of MFIs. That grew 16 -fold by the end of 2013 to 211 million clients worldwide, of which 114 million were the very poorest, those living on less than $\$ 1.90 /$ day. ${ }^{8}$ Other estimates vary, but all are similar in rough magnitude.

Of these hundreds of millions of microfinance clients, an estimated $75 \%$ are women. ${ }^{9}$ As we explore later in Chapter 7 on gender issues in microfinance, a common mission of many MFIs is to enhance the lives of women, particularly in regard to healthcare and empowerment. Indeed, some MFIs_-including Bharat Financial Inclusion Ltd. (BFIL), the largest MFI in India_cater exclusively to women. Every one of BFIL's more than 6 million clients is female. Note that BFIL (formerly called SKS) played a central role in the overall industry downturn in 2011, seen in Figure 1.4. That first-ever decline was largely related to turmoil in the large microfinance sector in India. 


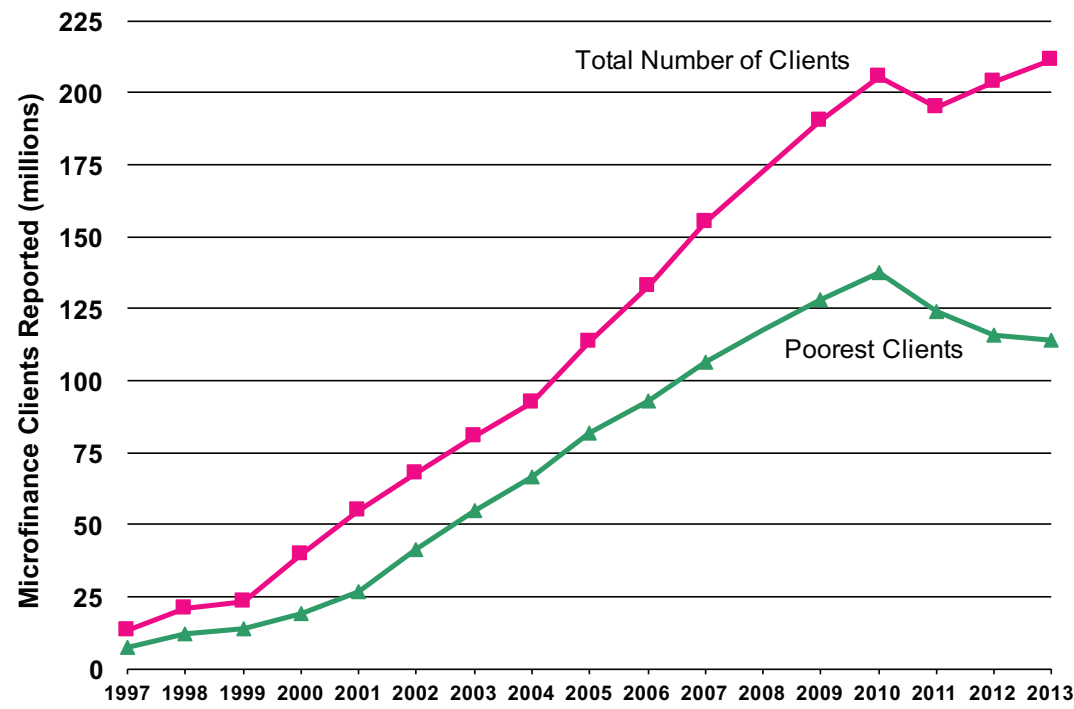

Figure 1.4. Growth in microfinance clients, 1997-2013

Data source: Microcredit Summit Campaign (2016).

\section{Who Provides Microfinance?}

The microfinance industry has become multilayered and fairly complex in industry structure. The industry is growing rapidly, has hundreds of millions of clients, and manages hundreds of billions of dollars in assets, loans and savings deposits. The many industry players continue to experiment with what works across all facets of the sector. Part of that experimentation is in the types of legal entities that MFIs can be. MFIs can serve a variety of niches and come in a variety of different legal structures, including those listed in Table 1.2.

These different legal statuses come with varying levels of freedom and regulation. A majority of MFIs are NGOs, often small and dependent on donors. NGOs are typically nonprofit organizations, community groups, church-affiliated programs, and so on that are not regulated by a government banking authority. Banking regulations aim to protect citizens who save their money in banks from losing those funds, such as through bank failures or fraudulent activities. Nearly all countries require banks that want to take deposits to become regulated, i.e. to have official banking licenses, which are given only to banks with solid financial strength, good record keeping systems, controls against theft and fraud, and other safeguards, all of which 


\section{Table 1.2. Types of MFIs}

Non-governmental organizations (NGOs)

Member-owned cooperatives

Nonbank financial institutions

Rural banks and agricultural development banks

State-owned banks, including postal banks

Commercial banks

can be costly to implement and maintain. Because becoming a regulated bank can be cost prohibitive, most NGOs elect not to. As a result, they cannot take deposits and are limited in how they can spend their funding.

Member-owned cooperatives take many forms, such as credit unions, village banks, or self-help groups, but generally provide services only to their members; regulations on cooperatives vary widely by country. Nonbank financial institutions are similar to banks but are classified under a different type of license. A government banking agency also typically supervises them. They usually have lower requirements in terms of how much capital they must have, and are limited in what types of services they can offer. Whether they can take deposits or not depends on the country. Some countries like Peru and Ghana have created special regulations targeted specifically at microfinance operations, allowing them to behave differently than traditional banks. Rural banks and agricultural development banks are regulated banks that operate in nonurban areas and focus mainly on the agricultural sector. Most were started as government-owned banks or private banks with heavy government subsidization. Purely state-owned banks are similar to the banks most of us normally think of, but are owned by the government. Commercial banks are the supervised for-profit banks with which most of us are generally familiar.

Adding to the complexity, any one of these types of organizations may deal primarily with something other than microfinance and only provide microfinance services as a peripheral to their main operations. For example, an NGO called World Relief focuses on providing health education and services, child development support, agriculture and food security, and disaster response, in addition to microfinance. ${ }^{10}$ Giant corporations, such as Wal-Mart, also dabble in microfinance internationally by creating operating 

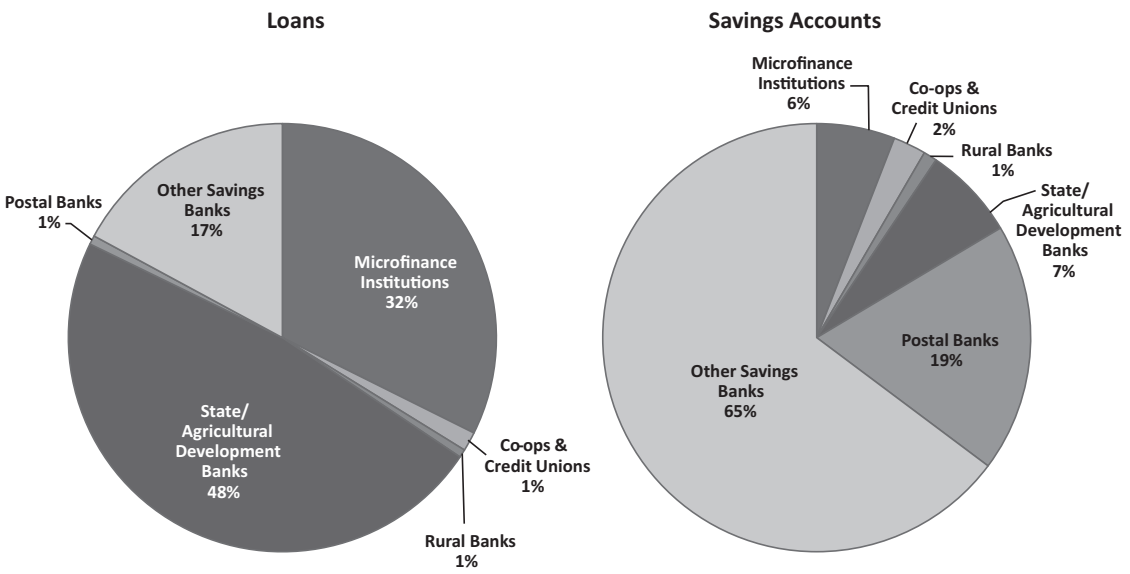

Figure 1.5. Share of savings accounts and active loans in alternative financial institutions

Data Source: Roodman (2012).

divisions that deal primarily with microfinance. In fact, a very large percent of microsavings accounts and active microloans comes from organizations that do not primarily engage in microfinance (Figure 1.5). Institutions that focus strictly on the provision of microfinance services make up minorities of both savings accounts $(6 \%)$ and active loans $(32 \%)$.

\section{Commercialization: Does It Undermine Social Missions?}

Increasingly, some NGOs and nonbank financial intermediaries have been transforming themselves into regulated banks. This allows them not only to meet their clients' demand for savings, but also to access savings deposits as a low-cost source of funding, and also to make investments in other types of activities that only regulated banks may do.

Most MFIs that have so far transformed into regulated commercial banks had their roots as an NGO, rural bank, or state-owned bank. For example, the very first MFI to transform was a non-profit NGO in Bolivia called Prodem, which in 1992 became the BancoSol, a for-profit regulated bank. Similarly, BRI in Indonesia and Compartamos Banco in Mexico both become for-profit companies with shareholders buying and selling ownership shares in the companies on stock markets. BRI had been a state-owned bank 
since 1946 until the Indonesian government sold some shares to the public in 2003. Compartamos Banco began in 1990 as an NGO, became a non-bank financial institution in 2000, and then a regulated bank in 2006, followed by its owners selling shares to the public in 2007 . We profile all these and many other leading institutions in later chapters.

Even at the birth of microfinance in the 1970s, a few institutions were managing microfinance with an approach more akin to commercial banks than to charities. A few pioneering MFIs in Indonesia, Latin America, and India began charging interest rates on loans that enabled them to cover all their costs while maintaining their borrowers' ability to repay. While these institutions proved early on that financial viability without charitable subsidies was possible for MFIs, it was not until the 1990 s that commercialization truly gained significant momentum. It is useful to understand the primary benefits from commercialization for the individual borrowers, MFIs, and the industry as a whole. As detailed in Chapter 8, these benefits include the lowering of interest rates through competition and lower costs from scale efficiencies and increased access to traditional capital markets, competitive incentives for more innovative financial products, and, importantly, greater long-term institutional sustainability. ${ }^{11}$

However, as institutions commercialize they become more and more responsible to their investors, who can put additional pressure on MFIs to generate profits. An argument often raised against the commercialization of microfinance is that a profit-seeking organization might lose its focus on serving the poor. Additionally, regulated institutions are required to have boards of directors that meet certain qualifications to guide the institution's governance. A new board may have directors with goals that differ from the NGO's founding vision. From this argument stems a vigorous debate in microfinance regarding mission drift: i.e. how commercialization might shift the goals and focus of an institution from generating returns for society (often called the social bottom line) to generating returns for shareholders (called the financial bottom line).

By adding shareholders to the equation, a commercial MFI now has two responsibilities: creating profits for its investors and providing superior products and services to improve the lives of its clients. This combination 
of commercial and social missions is often called the double bottom line. Unfortunately, even though the poorest of the poor may have the most immediate need for financial services, they are rarely the most profitable customers. Thus, an MFI that is increasingly concerned about profitability may tend to move away from the very poorest and serve clients that will earn them a higher return. So even though commercialization can potentially increase the numbers of clients reached, reduce costs to those clients, and create incentives for financial products better tailored to their needs, does it actually ensure outreach to the "right" clients? Or does it merely mean that a commercial MFI will increase its client base and asset portfolio by serving higher-income clients, thus actually decreasing poverty alleviation among those who need it the most?

There is currently no clear-cut answer, only the knowledge that socially driven NGOs still have an important role to play in the industry. Because NGOs have no pressure to generate a profit, they can more readily target the poorest of the poor. On the other hand, they have less capital with which to reach them and expand their services and have a harder time achieving economies of scale to reduce costs for clients.

\section{Outreach}

We have learned that something like 200 million clients are being served by microfinance institutions. But how poor are they? The answer to that question is concerned with what is called depth of outreach, or going down-market, which in financial industry jargon means serving poorer communities. For alleviating poverty, we might hope to see microfinance coverage emphasize areas with greater levels of poverty. Focusing on the correlation between the presence of microfinance and levels of poverty will help us better see the depth of outreach, not just the scale.

As you can see in Figure 1.6, many severely poor parts of Sub-Saharan Africa have limited microfinance coverage (lighter) while severely poor regions of Asia have strong (darker) microfinance coverage. It is curious as to why Asia is better served than Africa. Population density is one central factor; it is more cost effective for MFIs to serve many people when they live close together. Bangladesh has more than 1000 people per square kilometer, 50 times denser than Zambia at fewer than 20. Yet Peru has perhaps the most 


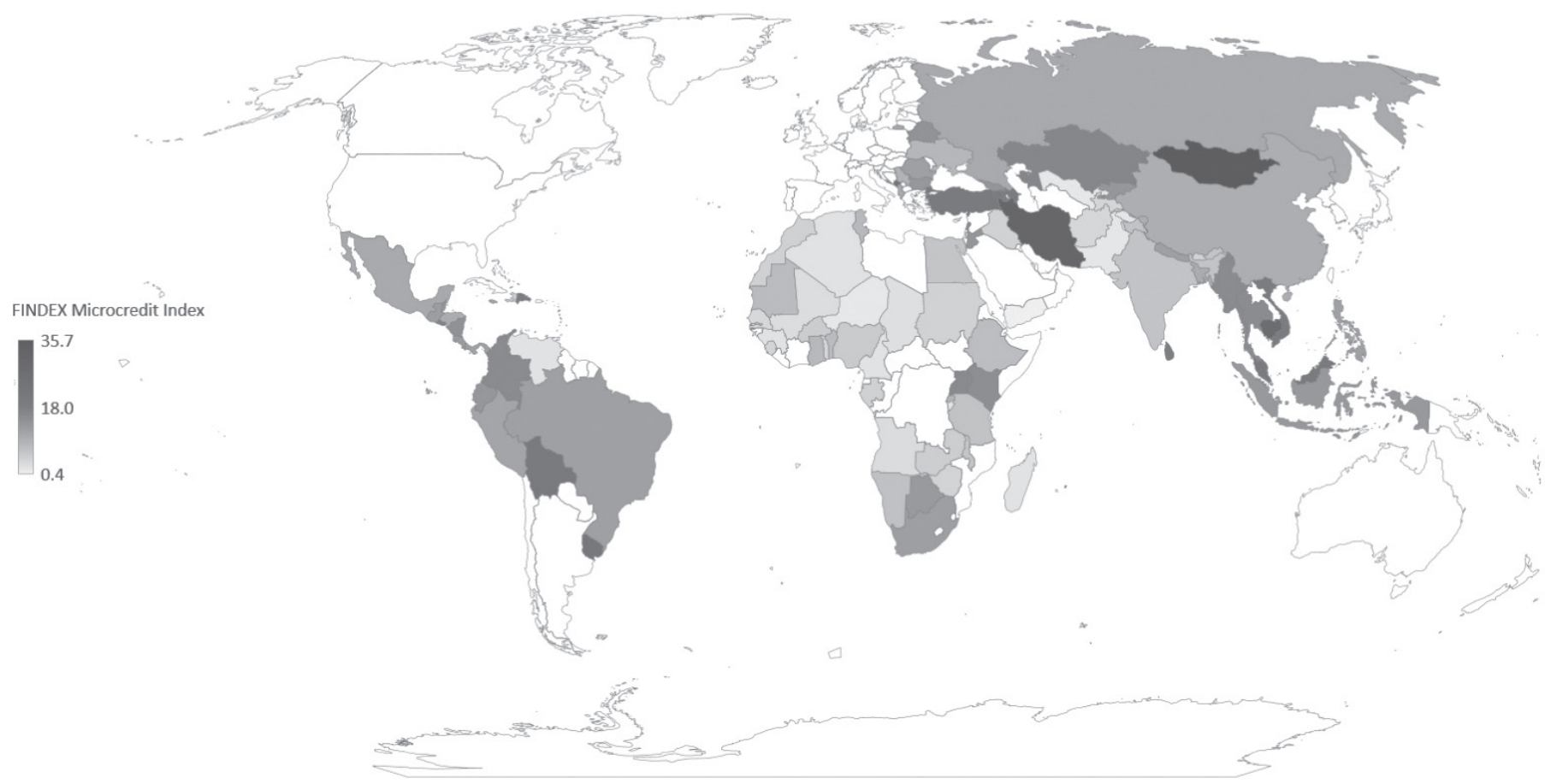

Figure 1.6. Global FINDEX Index of Microcredit Market Penetration

Note: Darker $=$ Greater penetration as share of potential market.

Source: World Bank, Global Findex Database, 2014. 
advanced microfinance sector in the world despite a population density very close to Zambia's.

Other key factors are government policies and economic and political stability. Historically, Asian governments have a better record when it comes to economic development, growth and political and regulatory stability. By contrast, various African nations regularly suffer political and economic upheavals, which make it difficult for MFIs to invest and serve the poor due to hostile regulatory environments, unpredictable economic swings, and sometimes high rates of domestic migration that displaces clients. In optimal environments, MFIs can set up branches and introduce various financial services to a settled client population, invest for the long haul without risk of the broader economy collapsing and with little difficulty from a regulatory perspective.

\section{Key Players and Intermediaries}

\section{Microfinance Institutions and Networks}

By reading this chapter you have already become somewhat familiar with the names of a few key players in the microfinance industry. Certainly, the major early microfinance innovators are still instrumental within the industry. In addition, within the past two decades, new MFIs have begun to emerge as leaders. Table 1.3 lists the top MFIs in each region according to number of borrowers.

MFIs can grow to be quite large, or in the case of South Asian MFIs, enormous. Among regions, Europe and Central Asia (ECA) has fewer borrowers, largely because the potential markets there for microcredit are simply relatively small. For example, Mongolia's Khan Bank captures one-third of Mongolia's entire estimated potential market for microcredit services. ${ }^{12}$ On the other hand, despite BRAC's 4.9 million borrowers, it only serves well fewer than one in 10 potential clients.

Hence, when looking at an MFI's impact it is important to consider both the scale and depth of its outreach, just as we must examine the scale and depth of the industry's outreach as a whole. Both a large gross number 


\begin{tabular}{lllr} 
Region & \multicolumn{1}{c}{ MFI } & \multicolumn{1}{c}{ Country } & borrowers \\
\hline East Asia and Pacific & BRI & Indonesia & $7,850,000$ \\
& ASA Philippines & Philippines & $1,073,580$ \\
& Card NGO & Philippines & 816,619 \\
Europe and Central & UniBank & Azerbaijan & 447,918 \\
Asia & Khan Bank & Mongolia & 358,914 \\
& CREDO & Georgia & 196,947 \\
Latin America and & Compartamos Banco & Mexico & $2,861,721$ \\
Caribbean & CrediAmigo & Brazil & $2,030,821$ \\
& AgroAmigo & Brazil & $1,097,759$ \\
Middle East and & Al Amana & Morocco & 328,361 \\
North Africa & ABA & Egypt & 283,979 \\
& Enda & Tunisia & 270,563 \\
Sub-Saharan Africa & Capitec Bank & South Africa & $3,684,000$ \\
& African Bank & South Africa & $1,500,000$ \\
& LAPO & Nigeria & 800,6111 \\
& Grameen Bank & Bangladesh & $8,806,779$ \\
South Asia & Bandhan & India & $6,717,331$ \\
& ASA & Bangladesh & $5,362,966$ \\
& BFIL (formerly SKS) & India & $5,325,244$ \\
& BRAC & Bangladesh & $4,923,936$ \\
\hline
\end{tabular}

Note: Clients as of 2015, except Capitec 2/2016, UniBank and LAPO 12/2014; and African Bank Ltd. as reorganized 4/2016. For consistency, the table does not include the Vietnam Bank for Social Policies or the Postal Savings Bank of China, large but essentially government-run subsidized banks.

Sources: Microfinance Information Exchange, www.mixmarket.org; Bank Rakyat Indonesia, Annual Report 2015; Capitec Annual Report 2016; Grameen Bank Monthly Report 12/31/2015.

of borrowers and a large share of the potential market, known as market penetration, are beneficial to helping alleviate poverty. A large number of clients indicates that many people have access to financial services. However, market penetration is still important because it means that a greater share of 
Table 1.4. Largest MFIs worldwide by number of depositors, 2015

\begin{tabular}{llc}
\hline MFI & Country & Number of depositors \\
\hline BRI & Indonesia & $43,000,000$ \\
Grameen Bank & Bangladesh & $8,806,779$ \\
Equity Bank & Kenya & $8,780,150$ \\
ASA & Bangladesh & $6,313,359$ \\
BRAC & Bangladesh & $5,799,933$ \\
Banco Caja Social & Colombia & $5,292,794$ \\
Tameer Microfinance Bank & Pakistan & $4,958,736$ \\
Capitec Bank & South Africa & $3,300,000$ \\
Khan Bank & Mongolia & $2,364,853$ \\
Caja Popular Mexicana & Mexico & $2,010,829$ \\
\hline
\end{tabular}

Sources: Microfinance Information Exchange, www.mixmarket.org; Bank Rakyat Indonesia, Annual Report 2015; Capitec Annual Report 2016; Grameen Bank Monthly Report 12/31/2015.

the community, no matter how small, is potentially better off. A stronger, financially empowered community as a whole can have greater externalities that help alleviate poverty. Community members are consequently able to help each other more effectively.

Remember, the figures in Table 1.3 only represent the number of people who have received credit from the listed MFI. Many of these MFIs also provide savings, thus they serve even more clients than these numbers reveal. Table 1.4 ranks the top 10 MFIs in terms of number of depositors.

BRI is clearly a very large outlier, serving nearly five times as many depositors any other microfinance deposit taker in the world. Overall, most of microfinance's depositors are found in Asia. Note overall that six of the 10 depositor-leading MFIs in Table 1.4 (including four of the top five) also appear in Table 1.3 as leaders in terms of scale of credit.

While many MFIs operate independently, some are part of larger collaborative structures. Network groups usually involve a central umbrella organization that assists a group of collaborating but separately managed 
member MFIs. Several of the very first MFIs have also become networks, such as Accion and FINCA. Think of network groups as a club of MFIs that usually have something in common such as region of operation or ideology. For example, Accion is a large network group with 35-member MFIs, such as Compartamos Banco in Mexico, MiBanco in Peru, and Akiba in Tanzania. Accion members are in 21 countries, predominantly in Latin America but also in Africa, Asia and even five in the U.S. ${ }^{13}$ Accion provides start-up and management aid to member MFIs, while simultaneously making concerted efforts at sharing best practices, promoting effective policies, supporting microfinance-related research and development, and offering technological services.

\section{MFI Funders and Service Providers}

In addition to MFIs and networks that directly provide financial services, a supporting layer of the industry involves the more than 100 investment institutions that raise funds specifically for MFIs. Among the best known are Oikocredit, and private investment groups like Triodos Microfinance Fund, Symbiotics, and BlueOrchard, which invest directly in MFIs by buying equity ownership shares or investing in debt securities. These microfinance investment vehicles attract large investors to long-term, potentially returngenerating securities that fund MFIs and other socially minded companies.

Not all such funders are as exclusive nor do all funds generate a return. For example Kiva.org allows internet users to fund microfinance directly through minimum investments of just $\$ 25$. Kiva works with MFIs on the ground that transfer your loaned funds to borrowers of your choice. The borrowers then makes repayments back to the MFIs, and in turn the repayments are credited to your Kiva account but without interest. The idea behind having the principal loaned amount paid back to the lender is simple: a majority of Kiva lenders use the money again to keep loaning to more people. MicroGraam.com in India works similarly, allowing internet users in India to fund clients of small non-profit NGOs doing microfinance in India. The minimum MicroGraam loan online is remarkably small, 100 rupees, less than $\$ 2$. MicroGraam even offers its investors the option of getting some interest. In 2014 MicroGraam and Kiva teamed up to open MicroGraam's partner NGOs to non-Indian investors through Kiva. Of course, there are also plenty of organizations that accept good oldfashioned donations. 
Service providers are a little harder to define. They are organizations that provide a service within the microfinance industry to MFIs or for the broader public interest in microfinance. Many undertake academic research on microfinance or initiate related development programs. Some, such as Omtrix in Costa Rica and Mecene Investment in South Africa, manage funds for MFIs. Others, like Mifos.org or Craft Silicon, provide technical services, such as banking software and database management computer systems, or enable MFIs and their clients to use ATM networks, credit cards, and mobile phone banking. Many network groups also provide services to member organizations, particularly when it comes to advocacy and policy. Another group includes the private rating agencies such as MicroRate and Planet Rating that evaluate the financial performance and social impact of individual MFIs. These offer investment-rating reports on specific MFIs for investors much like Standard \& Poor's does for stock market investors. Many of these reports are available on another service provider, the Microfinance Information Exchange (MIX), a leading source of detailed data on the industry. You will notice many of the tables and graphs in this book rely on MIX data.

\section{Box 1.4. In the Field Accion-The Business of Fighting Poverty}

Accion International has been innovating microfinance for more than 40 years, longer than any other organization. As a network, Accion has helped build and strengthen some of the most successful microfinance institutions in the world. Among their partner MFIs are BancoSol in Bolivia, Compartamos Banco in Mexico, Banco Solidario in Ecuador, and Bancompartir in Colombia to name a few. The network tends to focus on Latin America and the Caribbean, although Accion also has operations in Africa, Asia, and the U.S. It serves the microfinance community as a whole by providing services that build and expand other MFIs, advocating for improved policies, undertaking research and development, and providing technical services. Through its thinktank, the Center for Financial Inclusion, it works towards full, global financial inclusion with an emphasis on quality of services, dignity, transparency, affordability, and MFI sophistication.

(Continued) 
Box 1.4. (Continued)

\section{Table 1.5. Accion International}

\begin{tabular}{ll}
\hline Began microfinance operations & 1973 \\
\hline Locations & Latin America, Asia, Africa, and U.S. \\
\hline Clients (2015) & 6 million borrowers; \\
& 4.8 million savers \\
\hline Women as \% of clients & $75 \%$ \\
\hline Self-sufficiency ratio & Varies across 35-member institutions \\
\hline Legal status & Non-profit \\
\hline
\end{tabular}

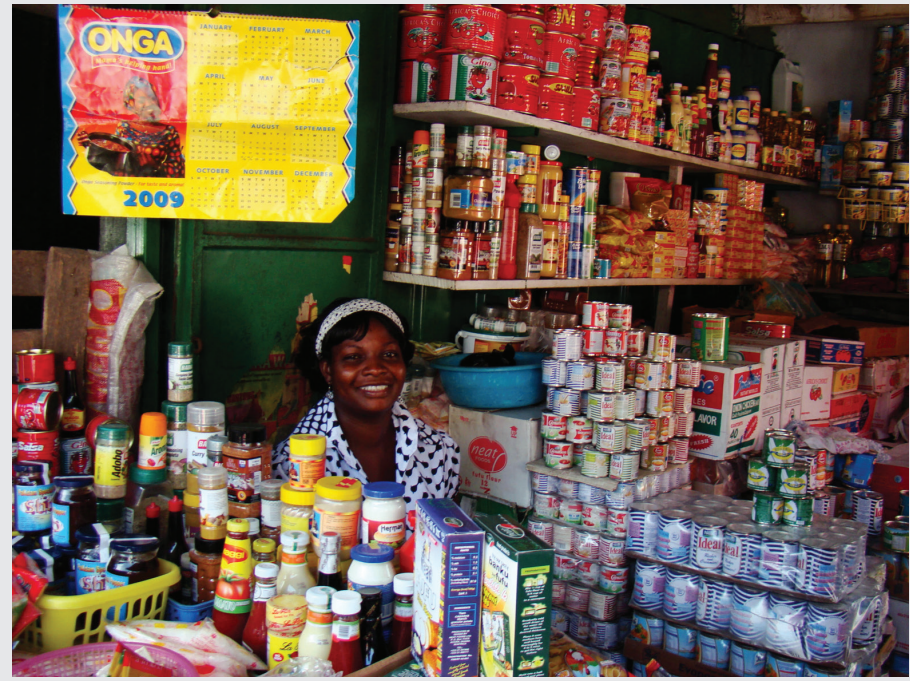

Figure 1.7. Microfinance client microentrepreneur and her grocery near Accra's Tudu market, in Ghana, where Pan-African Savings and Loans serves about 78,000 clients like her

Note: Pan-African Savings and Loans is a partnership of Accion and EcoBank, West Africa's top independent regional bank.

From 2004 to 2015, Accion and its partners disbursed more than $\$ 70$ billion in microloans to more than 19 million clients. Three of four of the network's clients are women and it boasts a worldwide repayment rate of $97 \%$. 
The CGAP and the Microcredit Summit Campaign are two other very well-known service providers. The Microcredit Summit Campaign organizes large meetings of microfinance leaders to talk about industry trends, goals, and issues, and to identify and share best practices. They also advocate women's issues and healthcare and publish a widely read annual report on the current state of the microfinance industry. That industry growth graph you saw earlier, Figure 1.4, uses data from that report. CGAP is a consortium jointly funded by more than 30 public and private development organizations, including the World Bank, the U.S. Agency for International Development, the United Nations Development Program, the European Investment Bank, and the Gates Foundation. CGAP offers advisory and technical services, training, research and analysis, and fosters development of industry standards, performance metrics and impact assessment. CGAP also often suggests potential innovative products, financing methods, management techniques, and ways to use new technologies.

Without service providers, microfinance institutions would confront greater obstacles both individually and industry-wide. Individual MFIs would face financing and expansion problems and have a harder time keeping up with new ideas, best practice management techniques and the latest technologies. On the industry level, service providers help set standards, propose and lobby for policies, and facilitate communication throughout the industry.

\section{Section in Bulletpoint}

- Microfinance has grown tremendously over the last few decades to more than 10,000 MFIs serving more than 200 million people, but access to microfinance is highly variable across countries.

- The largest MFIs each serves millions of clients.

- MFIs can take on different legal forms; those forms can limit the types of funding the MFIs can accept. Because of this, some NGOs go on to apply for banking licenses.

- External funds for MFIs come both from investors, such as specialized microfinance investment vehicles looking for a return on their funds and from conventional charitable donations.

(Continued) 
- The double bottom line means MFIs must balance financial returns and sustainability with social goals in poverty alleviation.

- Asia and Latin America are the largest microfinance markets.

- The industry is supported by a layer of service providers that provide advice on best practices, ratings for investors, technology, fund management, advocacy, industry standards, and research.

\section{Discussion Questions}

1. Suppose an MFI is currently an NGO but is considering becoming a regulated bank. What are some pros and cons? In particular, how would the change affect the services they could offer, their funding source options, and their institutional governance?

2. What factors might help contribute to an MFI's ability to increase its scale? What about for an MFI that wants to improve its depth of outreach?

3. What reasons can you think of that might help explain why there are some places where there is severe poverty yet no or little microfinance?

4. If you were to run a microfinance institution, what key issues and tensions do you think would arise as you decide how to balance the double bottom line of financial performance and social mission to help the poorest? Is one more important? What could you do to try and meet both goals?

\section{Chapter Summary}

Poverty continues to affect billions of lives across the globe. Microfinance is but one tool of many that strives to alleviate poverty. Specifically, microfinance serves the demand the poor have for financial services. The poor have been traditionally excluded from formal financial services, but through innovative financial products, such as group lending, microfinance institutions have been able to address the challenges in lending to the poor while delivering products-microcredit, microsavings, insurance, and more-that can help clients lift themselves and their families out of poverty.

With the help of network organizations, microfinance investment vehicles, donors, and technical support providers, microfinance institutions attempt 
to reach the underserved and to include them as fully as possible in financial systems around the world. This effort has grown from a handful of organizations serving a few clients to many thousands of microfinance institutions reaching hundreds of millions of low-income people across the globe.

The following chapters will take a closer look at poverty, microfinance, the industry, the impact of microfinance on the poor, and the key players that make microfinance possible.

\section{Key Terms}

\section{depth of outreach}

A gauge of how poor microfinance clients are relative to others in a given service region and the degree to which financial services are available to the very poorest.

\section{down-market}

Related to depth of outreach, MFIs that serve very low-income clients are said to go down-market; also true for other financial industries.

\section{double bottom line}

The dual goals of ensuring financial sustainability while also focusing on social goals in poverty alleviation.

\section{group lending}

Providing loans jointly to groups of people. A key innovation that helped foster the rapid growth microfinance; remains a dominant practice in the industry.

\section{market penetration}

Refers to the share of a potential market served; for MFIs, often measured as a percentage of potential clients or of potential value of loans or deposits.

\section{microcredit}

Also called microloans; small-value loans, often given without the need for collateral.

\section{microfinance}

The provision of financial services to underserved populations. Financial services offered to the poor include different forms of financing, varying from credit and savings to insurance and pension funds. 


\section{microfinance institution (MFI)}

An entity that provides financial services to the poor. MFIs vary in form from NGOs to non-banking financial institutions to regulated e-banks.

\section{microfinance investment vehicles}

Investment groups that invest in MFIs; often pool private equity shares or debt securities for socially minded investors and companies.

\section{mission drift}

Refers to when an MFI shifts from helping the poor to a focus on financial returns.

\section{network groups}

Large, collaborative umbrella organizations that assist individual member MFIs in reaching their social and financial goals through financial, technical, and managerial assistance.

\section{self-sufficient}

An institution that covers its own cost and therefore does not require subsidies or donations.

\section{service providers}

Organizations that provide a service, such as academic research, fund management, and rating agencies, within the microfinance industry to MFIs and/or the public interest. They usually serve to promote microfinance policy and advocacy.

Notes:

\footnotetext{
${ }^{1}$ Cruz et al (2015).

${ }^{2}$ See www.accion.org/content/1970s-microlending-begins

${ }^{3}$ Microcredit Summit Campaign (2016).

${ }^{4}$ Christen, Rosenberg, and Jayadeva (2004).

${ }^{5}$ Rosenberg et al (2013).

${ }^{6}$ Roodman (2012).

${ }^{7}$ Microfinance Information Exchange (2009).

${ }^{8}$ Microcredit Summit Campaign (2016).

${ }^{9}$ Microcredit Summit Campaign (2016).

${ }^{10}$ See www.worldrelief.org/about

${ }^{11}$ Robinson (2001).

${ }^{12}$ Microfinance Information Exchange (2010).

${ }^{13}$ Accion International (2015).
} 